Egyptian Journal of Aquatic Biology \& Fisheries

Zoology Department, Faculty of Science,

Ain Shams University, Cairo, Egypt.

ISSN $1110-6131$

Vol. 22(2): 163- 171 (2018)

http://ejabf.journals.ekb.eg/

\title{
Ultrastructure studies on Retina and Cornea of Octopus macropus from Egyptian
} Mediterranean Coasts

\author{
Tarek G. Ali \\ Zoology Dept., Faculty of Science, Ain Shams University, Cairo, Egypt. \\ tarekali80@yahoo.com
}

\section{ARTICLE INFO}

\section{Article History:}

Received:May 15, 2018

Accepted: June19, 2018

Available online: July 2018

\section{Keywords:}

Octopus macropus

Mediterranean Coast

Retina

Cornea

Ultrastructure

\begin{abstract}
Adult animals of Octopus macropus were collected alive from Abu Quir coasts, Alexandria, Egypt. They were transported to the laboratory at Faculty of Science, Ain Shams University and dissected to obtain their eyes and put in suitable fixative. After that, the routine ultrastructure techniques were applied for examination of the retina and cornea by the transmission electron microscope. The results revealed that the retina is formed of two layers; the visual cells and the connective tissue. The visual cells contain a small amount of a granular endoplasmic reticulum, rounded mitochondria and oval nuclei with distinct nucleoli. From each four different visual cells, four rhabdomeres united to form a prismatic rhabdome. Examination with higher magnification power showed presence of groups of 8 to 9 lamellated structures that form dense membranes with different lengths. These lamellated structures are similar to the myelin membranes and present in all cells but not connected to the plasma membrane. The cornea is made of three layers; the outer epithelial layer of hexagonal cells that have small mitochondria and oval nuclei. The median thick layer of fibrous connective tissue and the inner endothelium layer of cuboidal cells having small mitochondria and large rounded nuclei.
\end{abstract}

\section{INTRODUCTION}

A very little work has been done on the ultrastructure of octopus eye and how can octopus see in the deep waters? Octopus and Human eyes focus light to retina in different ways. Humans accommodate their eyes into focus by changing the shape of the lenses using muscles. On the other hand, octopus focuses by moving the lenses near to or further away from the retina by the same way of the camera; referring cephalopod eyes as "Camera eye"(Yamamoto, et al. 1965). The eyes of squid, octopus, cuttlefish and noutiloids are similar to that of the vertebrates in having cornea, lens and retina (Young 1974).

The polarization sensitivity (PS) in two species of cuttlefish; Sepia plangon and Sepia mestus using wide-field optomotor stimuli were studied (Talbot and Marshall, 2010). Construction of model of computer for studying the visual system in cephalopods (Octopus, cuttlefish and squid), that have single unfiltered photoreceptor mechanism was discussed (Stubb and Stubbs, 2016). The fine structure of the visual cells and the retinal plexiform layer of Octopus vulgaris were studied by the electron microscopy ( Tonosaki, 1965). 
The structure of cephalopod eye lens was studied (Willekens, et al. 1984), and these previous authors found that in Sepiola atlantica the lens consists of two distinct halves. The modulation transfer function (MTF) of visibility of some aquatic animals was discussed (Jagger and Muntz, 1993). The distribution of Retinol isomerase in some aquatic vertebrate eyes and during retinal development was investigated (Bridges, 1989). The growth and optical similarities between lens of some cephalopods were studied ( Sivak et al. 1994). The molecular and structural studies on cephalopod rhodopsin were discussed (Kzuko et al. 1979). The objective of the present study is to investigate the retina and cornea of Octopus macropus by the transmission electron microscope.

\section{MATERIALS AND METHODS}

\section{Tissue processing for microscopical examination:}

The retina and cornea of Octopus macropus were separated from the eye rapidly and then they were cut into sections. Glutaraldehyde $(2.5 \%)$ in $0.1 \mathrm{M}$ cacodylate buffer was used for fixation of the sections at $4{ }^{\circ} \mathrm{C}$, for 4 hours. Then, the sections were washed in $0.1 \mathrm{M}$ Cacodylate buffer. Osmium tetroxide $(1 \%)$ was used for post-fixation for 2 hours. Then, the sections were dehydrated in ascending series of ethyl alcohol and cleared in propylene oxide. Finally, they have been embedded in the epoxy resin. The polymerized resin blocks were cut by using the ultramicrotome (American Optical Co, USA), and glass knives into semithin sections " $1 \mu \mathrm{m}$ thick". Then, these sections were routinely stained for examination by the light microscope and taking photos by a digital camera. In addition, ultrathin sections " $60 \mathrm{~nm}$-thick" were obtained by using the diamond knife and the same ultramicrotome, and then stained with lead citrate and uranyl acetate. Finally, the transmission electron microscope (JEOL, 1200 EXII, Tokyo, Japan) was used to examine the ultrathin sections.

\section{RESULTS AND DISCUSSION}

\section{Structure of the Retina:}

a) Examination of the semithin sections of the retina by the light microscope (Fig. 1):

Examination of the retina by the light microscope revealed that it is composed of two layers; the first one consists of the visual cells. This layer contains; i) the outer distal parts of the visual cells that appear long and slender and ii) the darklystained inner proximal parts of the visual cells. The second layer is the lightly-stained plexiform layer, which consists of connective tissue and has blood vessels.

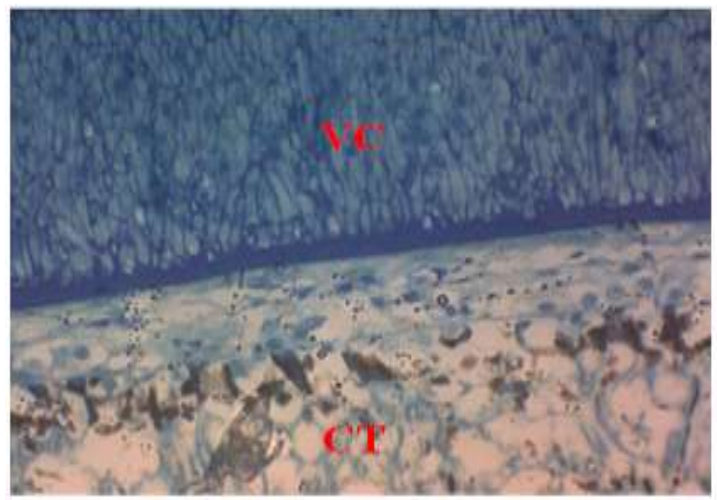

Fig. 1: A photomicrograph of retina showing visual cells (VC) and connective tissue (CT). 


\section{b) Examination of the ultrathin sections of the retina by the transmission electron microscope:}

The ultrastructural examination showed that the visual cells contain a small amount of a granular endoplasmic reticulum, also many rounded mitochondria were noticed. The distal parts of the visual cells have large and oval nuclei that contain accumulated chromatin and distinct nucleoli (Fig. 2). From each four different visual cells, there were four rhabdomeres that united to form a prismatic rhabdome on distal parts.

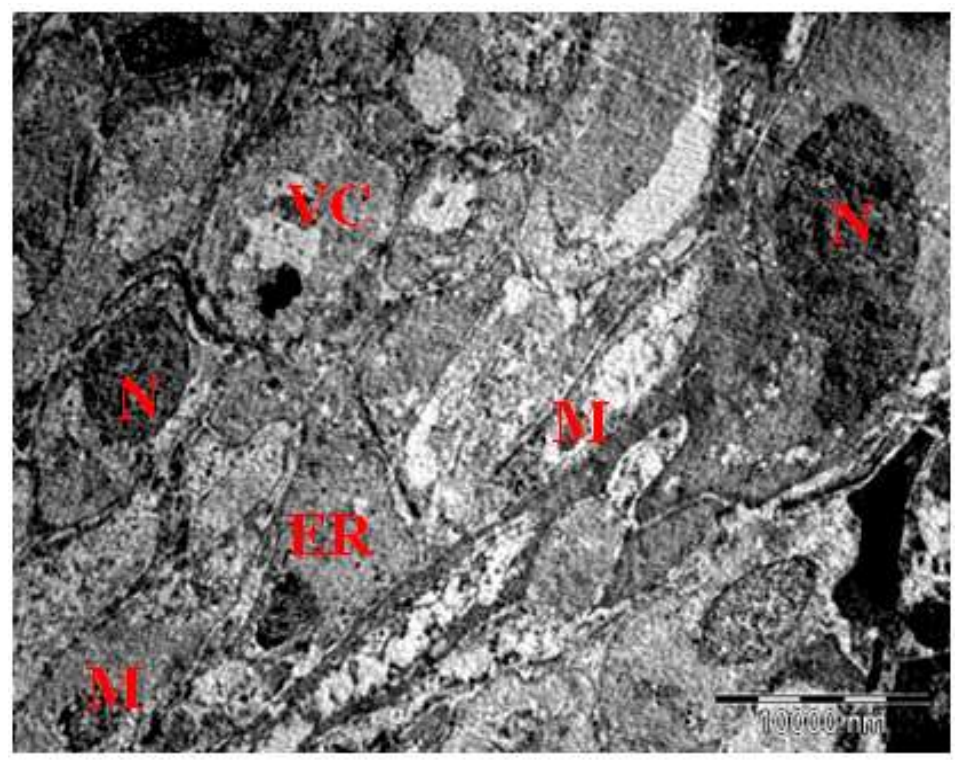

Fig. 2: An electronmicrograph of visual cells (VC) of retina showing nuclei $(\mathrm{N})$, endoplasmic reticulum (ER) and mitochondria (M).

Distally, towards the lower parts of the rhabdomes, there are supporting cell bodies that have a number of slender cytoplasmic processes at the bases of these cells (Figs. 3, 4 and 5).

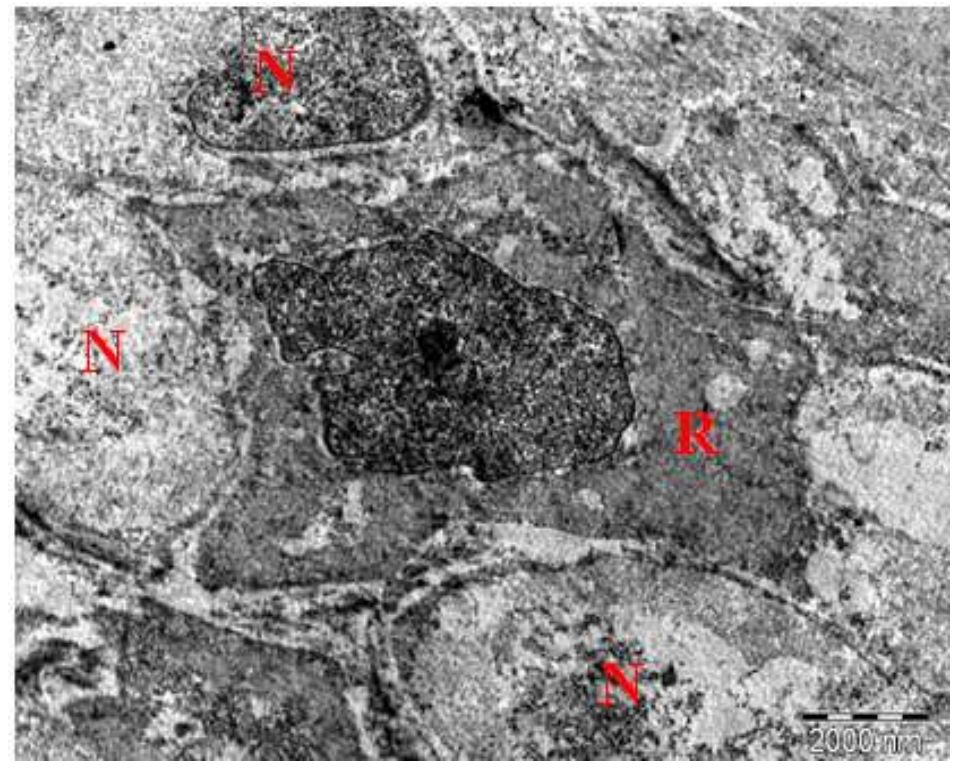

Fig. 3: An electronmicrograph of retina showing rhabdome $(\mathbf{R})$. 


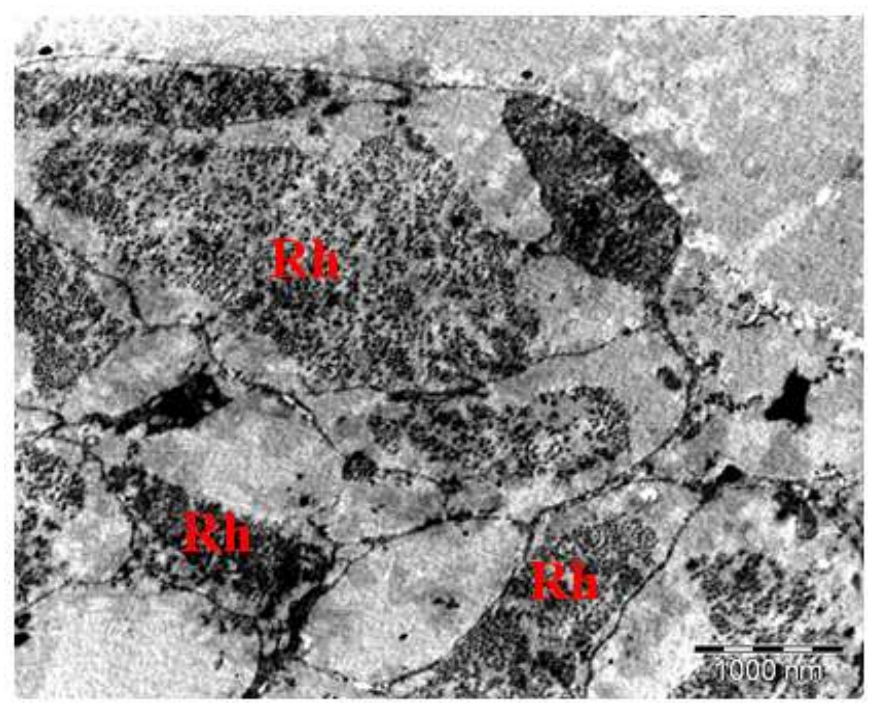

Fig. 4: An electronmicrograph of retina showing the rhabdomeres (Rh).

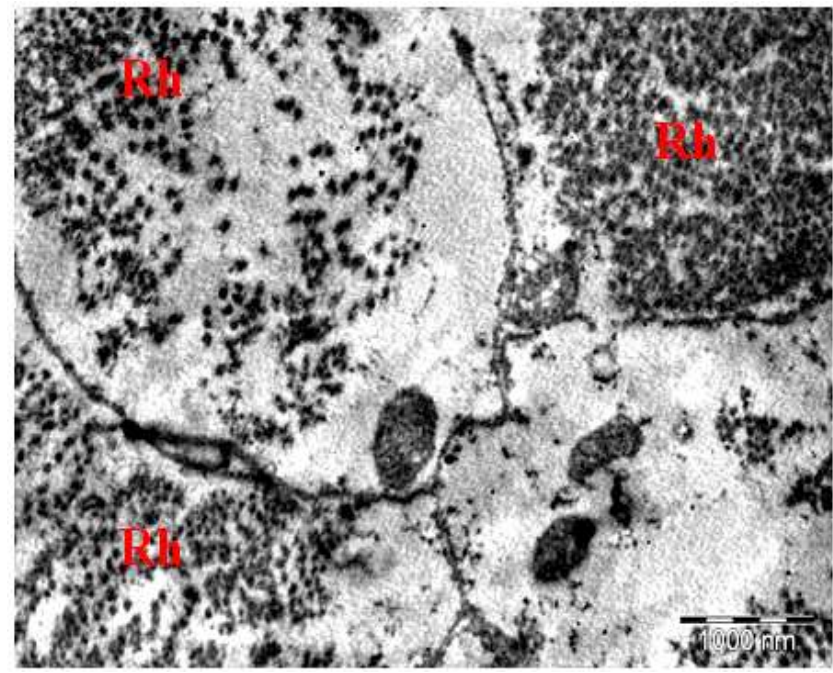

Fig. 5: An electronmicrograph of retina showing rhabdomeres (Rh).

Examination with higher magnification power showed presence of groups of 8 to 9 lamellated structures that form dense membranes with different lengths. These lamellated structures are similar to the myelin membranes and present in all cells but not connected to the plasma membrane (Fig. 6).

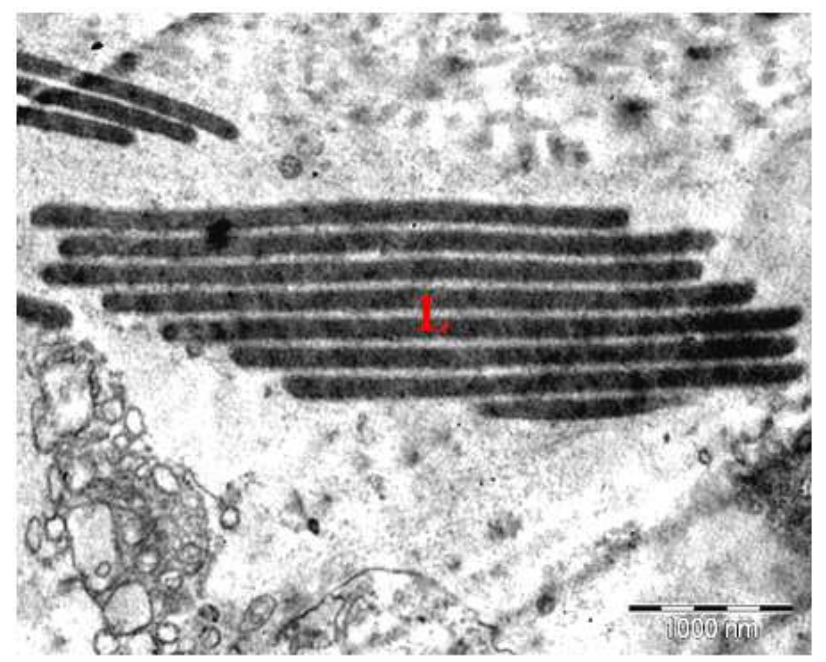

Fig. 6: An electronmicrograph of showing the lamellated myelin-like structure (L). 


\section{Structure of the Cornea:}

a) Examination of the semithin sections of the cornea by the light microscope (Fig. 7):

Examination of these semithin sections by the light microscope showed that the cornea is composed of three layers. The first one; the outer epithelial layer is formed of hexangonal cells that appear as three or four sub-layers. The second layer is the largest one of the cornea and is made of fibrous connective tissue. The third layer is called the endothelium that forms a basement sheet of the cornea.

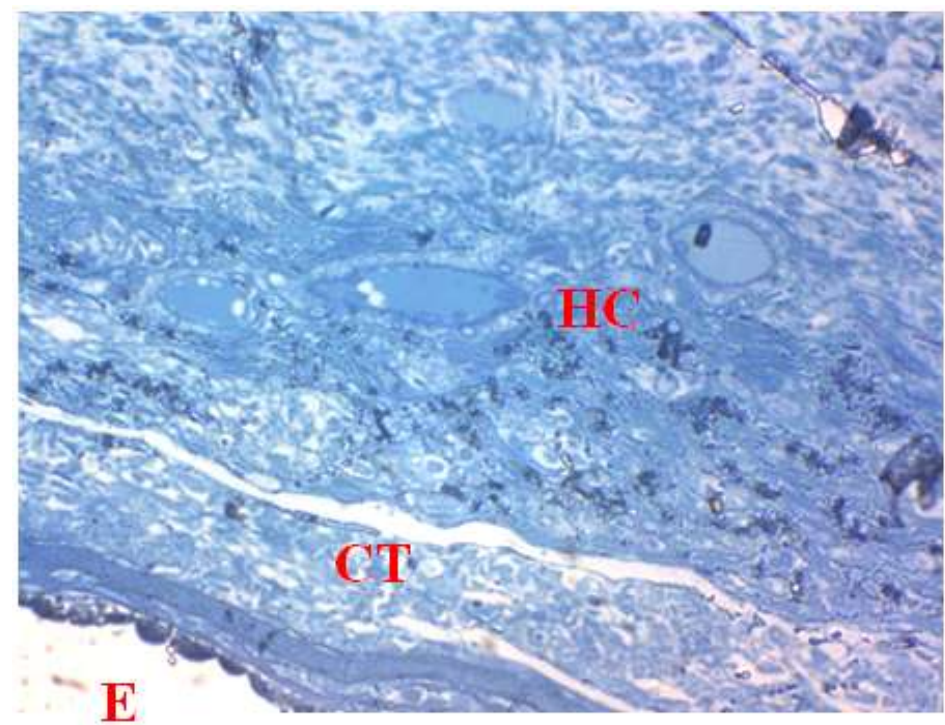

Fig. 7: A photomicrograph of cornea showing the outer epithelial layer of hexagonal cells (HC), the fibrous connective tissue layer (CT) and the endothelium layer (E).

b) Examination of the ultrathin sections of the cornea by the transmission electron microscope:

The hexagonal cells of the outer epithelial layer of cornea appear small at the outer borders and large at the inner side of this layer (Fig. 8).

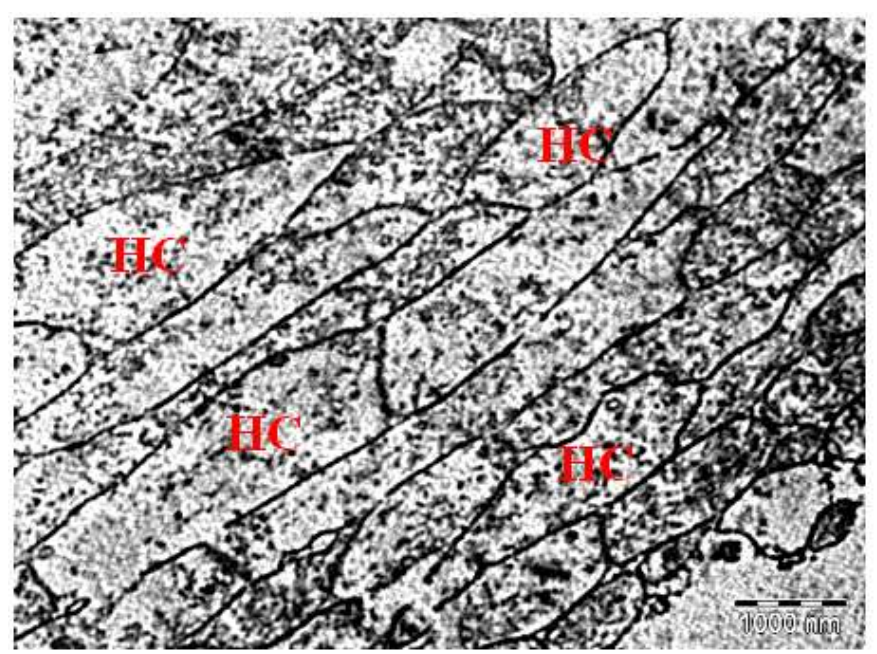

Fig. 8: An electronmicrograph of cornea showing the outer epithelial layer of hexagonal cells (HC).

These cells have granular endoplasmic reticulum and small mitochondria (Fig. 9), small and oval nuclei (Fig. 10).

The median layer is the largest one and represents about $80 \%$ of the thickness of the cornea. It has massive bundles of fibrous connective tissue (Fig. 11). The 
endothelium of the cornea is formed of cuboidal cells. Each cell has small mitochondria and large rounded nucleus (Fig. 12).

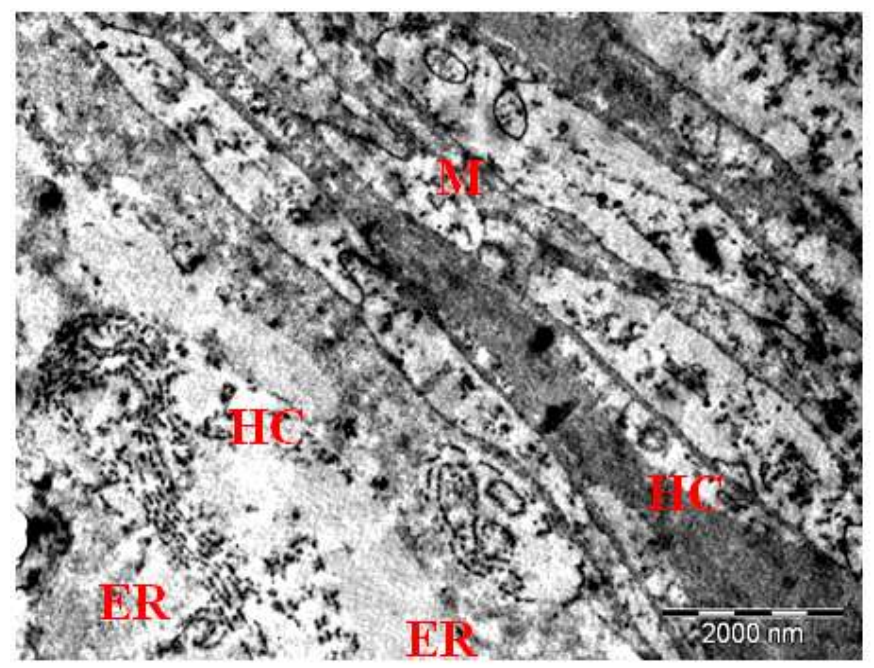

Fig. 9: An electronmicrograph of cornea showing the outer epithelial layer of hexagonal cells (HC) that have granular endoplasmic reticulum (ER) and small mitochondria (M).

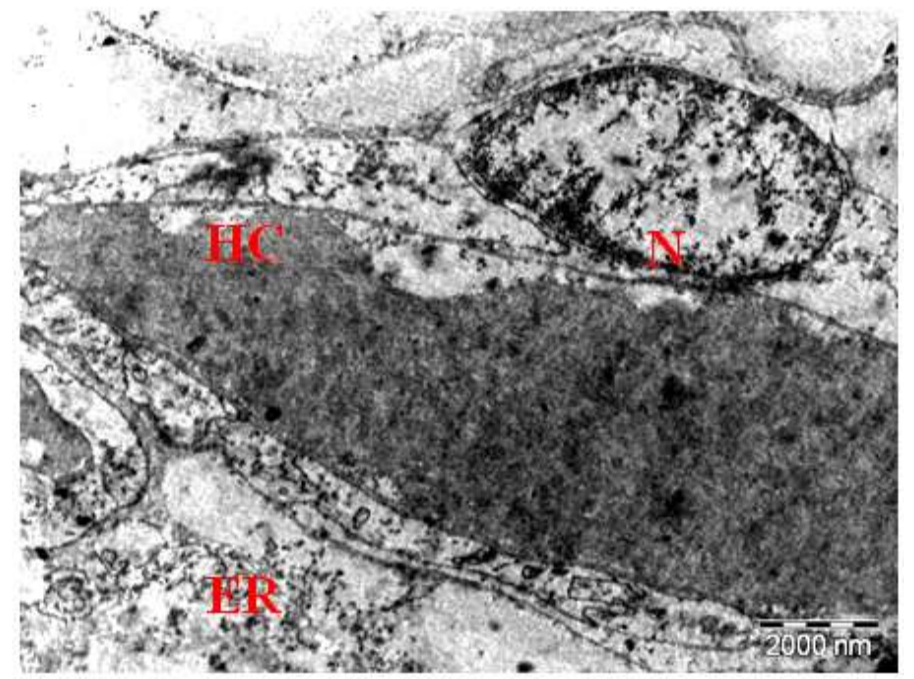

Fig. 10: An electronmicrograph of cornea showing the granular endoplasmic reticulum (ER) and the small oval nucleus of the hexagonal cells.

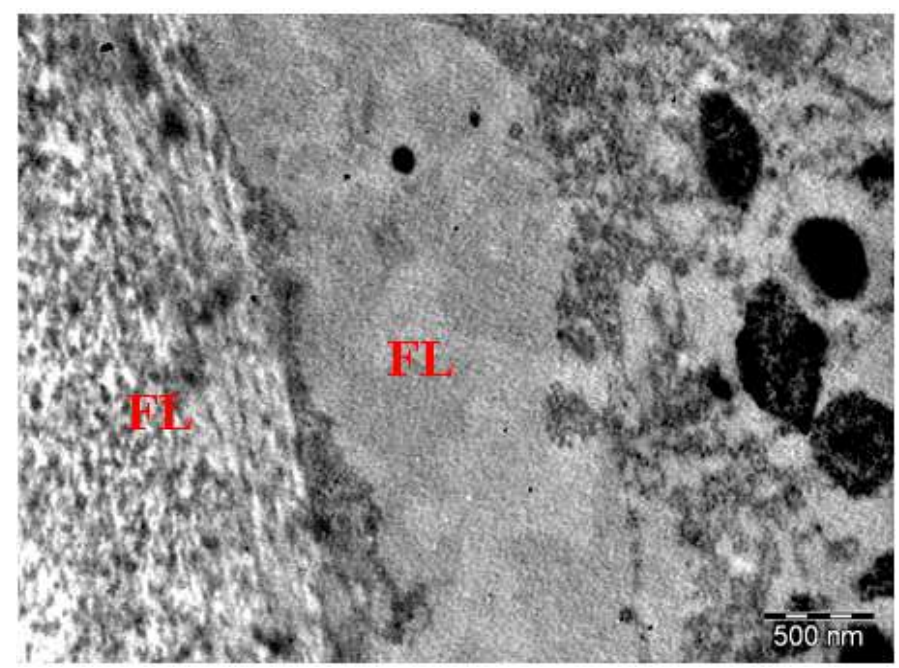

Fig. 11: An electronmicrograph of cornea showing the thick median fibrous layer (FL). 


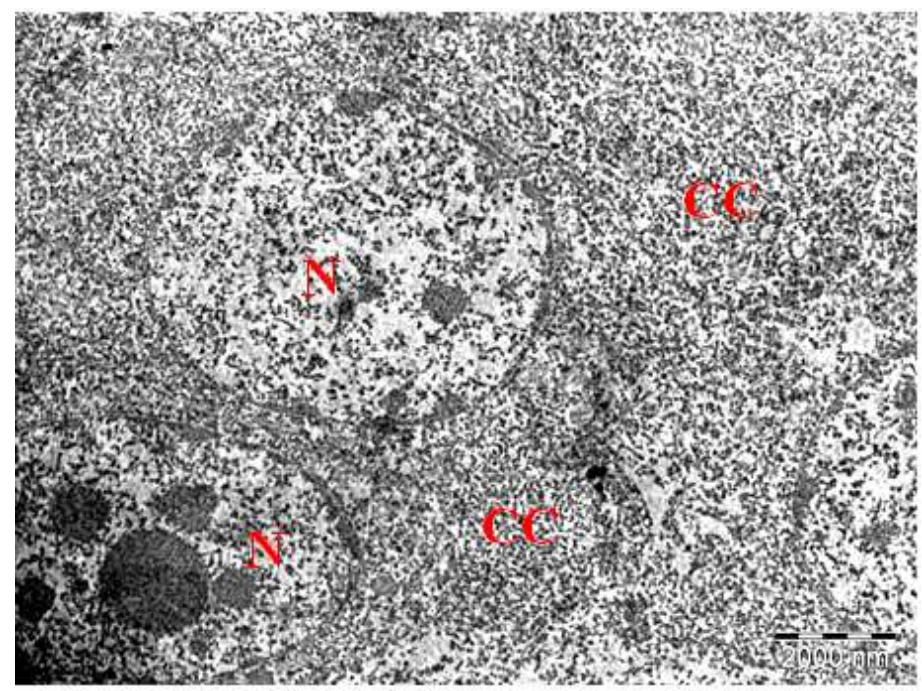

Fig. 12: An electronmicrograph of cornea showing the large round nuclei $(\mathrm{N})$ of the cuboidal cells (CC) of the endothelium.

\section{DISCUSSION}

The current study showed that the histology and the fine structure of the retina and the cornea of $O$. macropus are similar to those of the other cephalopods and have very little differences in comparison to them. This study revealed that the visual cells of $O$. macropus have dense membranes of lamellated structures found in groups "between 8 to 9". These dense membranes are similar to the myelin membranes but without a connection with the plasma membranes. Almost, similar findings of the structural features of retina and cornea were revealed in previous studies carried out by other authors (Yamamoto et al., 1965). Very little differences were found between the fine structure of the retina of O. macropus and that of $O$. vulgaris. Such differences included the following important points; lamellated structures of the visual cells were found in groups in both cephalopods, but were not connected to the plasma membranes in O. macropus, only. While in O. vulgaris, these lamellated structures were connected to the plasma membranes of the visual cells and were also present in groups in each cell with different lengths( Yamamoto , et al. 1965). Rhabdomes in the visual cells of the retina of $O$. macropus; may play an important role in the reflection of light for the octopus vision. However, in bony fishes like Sardinella aurita, Mostafa (2016) found that the retina structure is basically as in vertebrates and has well developed retinal pigment epithelium that is responsible for light reflection.

The present study revealed the presence of the outer epithelial layer in the structure of the cornea of the eye of O. macropus. This epithelial layer is mostly acting as a protective layer of the cornea to the eye. While cornea of the fish; S aurita has not large reflective incident like that in vertebrate, but It - as a whole structure acts as a protective cover of the fish eye ( Mostafa, 2016). Therefore, the current author suggested that the retina and cornea of the eye of $O$. macropus differ widely than that of fishes.

Earlier studies showed that there are some similarities between cornea of frog and mammals, especially in the three essential layers; the outer epithelium, the middle connective tissue and the inner endothelium, but it differs from that of Octopus. As in Octopus, the outer epithelial layer is formed of hexagonal cells like those of the retina of frog but cells are wider than that in frog and each cell has smaller nucleus than that in frog( Kaye , 1962). 
The fine structure of retina of Todarodes pacificus and Octopus minor was studied by earlier authors ( Han and Chang , 2002). They found that the rhabdome consists of four rhabdomeres and the area of rhabdome of $O$. minor is larger than that of $T$. pacificus. These findings come in agreement with the present results as the rhabdome of $O$. macropus consists of four rhabdomeres.

As far as the present author is aware, no earlier studies on the ultrastructure of the retina and cornea of $O$. macropus were done. Therefore, the author recommends carrying out more studies in such field as the structure and functions of different organs are related to the biodiversity and the habitats of different living organisms. Moreover, cephalopods have camera-like eyes and lie among highly developed light sense organs in animal kingdom as they show similarity with those of the vertebrates( Ogura, et al. 2004).

\section{REFERENCES}

Bridges C. D. (1989). Distribution of retinol isomerase in vertebrate eyes and its emergence during retinal development. Vision Res., 29 (12): 1711-1717.

Han j-M. and Chang N-S. (2002). Fine structure of retinae of cephalopods (Todarodes pacificus and Octopus minor) inhabiting the Korean waters I. Applied Microscopy., 32(1): 17-30.

Jagger W. and Muntz W. (1993). Aquatic vision and the Modulation transfer properties of unlighted and diffusely lighted Natural waters. Vision Res. 33 (13): 1755-1763.

Kaye G. (1962). Studies on the cornea III the fine structure of the Frog cornea and the uptake and transport of colloidal particles by the cornea in vivo. J. of Cell Biol., 15: 241-258.

Kzuko, K.; Mitsudo, M. and Kito, Y. (1979). Molecular weight and structural studies on cephalopod rhodopsin. Bioch. et Biophys. Acta (BBA)-Protein structure., 579 (1): $155-168$.

Mostafa A. S. (2016). Structure and function of the retinal pigment epithelium, photoreceptors and cornea in the eye of Sardinella aurita (Clupeidae, Teleostei). J. of Basic \& Applied Zool., 75: 1-12.

Ogura, A.; Ikeo, K. and Gojbori, T. (2004). Comparative analysis of gene expression for convergent evolution of camera eye between octopus and human. Genome Res. ; 14: 1555-1561.

Sivak, J. G.; West, J. A. and Campbell, M. C. (1994). Growth and optical development of the ocular lens of the squid (Sepioteuthis lessoniana), Vision Res., 34(17): 2177- 2187.

Stubbs, A. and Stubbs, C.(2016) Spectral discrimination in color blind animals via chromatic aberration and pupil shape. PNAS. , 113 (29): 8206-8211.

Talbot, C. M. and Marshall, J. (2010). Polarization sensitivity in two species of cuttlefish-Sepia plangon (Gray 1849) and Sepia mestus (Gray 1849) demonstrated with polarized optomotor stimuli, J. Exp. Biol. , 213: 3364-3370.

Tonosaki A. (1965). The fine structure of the retinal plexus in Octopus vulgaris, Zeitschrift für zellforschung. ; 67:521-532.

Willekens, B.; Vensen, G.; Jacob, T. and Duncan, G.(1984) The ultrastructure of the lens of the cephalopod Sepiola: A scanning electron microscopic study. Tissue and Cell. , 6 (6): 941-950.

Yamamoto, T.; Tasaki, K.; Sugawara, Y. and Tonosaki, A. (1965). Fine structure of the Octopus Retina, J. of Cell Biol. , 25: 345-359. 
Young, J. Z. (1974). "The Central Nervous System of Loligo I. The Optic Lobe." Phil. Trans. R. Soc. London. Series B, Biol. Sci. ; 267 (885): 263-302. http://www.jstor.org/stable/2417221.

\section{ARABIC SUMMARY}

دراسات على التركيب الاقيق للشبكية والقرنية للأخطبوط Octopus macropus من شؤطئ البحر المتوسط فى مصر

$$
\text { قسم علم الحيوان - كلية العلوم - جامعة عين شمس. }
$$

تم در اسة التركيب الدقيق للشبكية و القرنية للأخطبوط Octopus macropus من شؤطئ البحر المتوسط فى مصر بالميكروسكوب الإلكتروني النافذ.

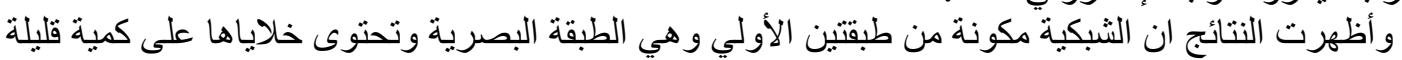

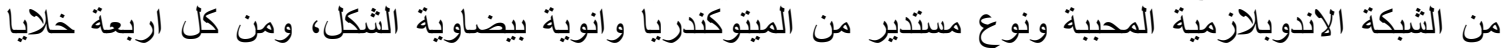

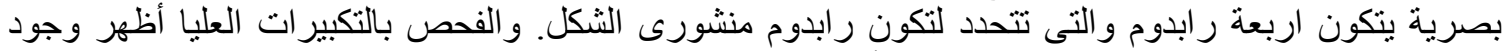

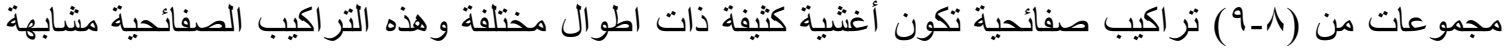

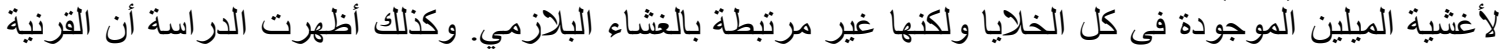

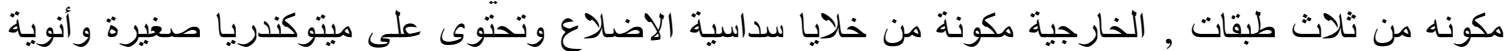

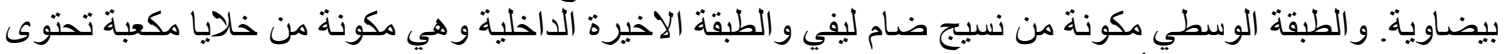

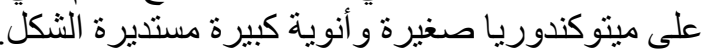

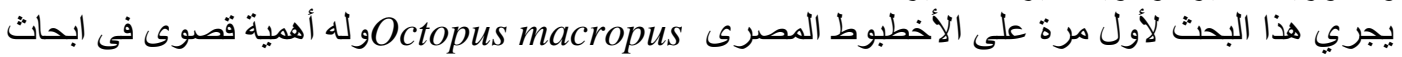
الروية تحت الماء. 